\title{
Unilateral Actions and the Rule of Law in Maritime Boundary Disputes
}

\author{
Anne Hsiu-An Hsiao
}

\section{I \\ Introduction}

The development of the modern international law of the sea regime has allowed States to extend their territorial claims and exercise of sovereignty beyond the traditional spatial domain. However, this has also led to overlapping maritime territorial or boundary claims among countries, resulting in an increase in the number of international disputes. States which face such kinds of situations often take unilateral measures to consolidate their own legal positions and safeguard important national interests, as international law imposes a certain disadvantage to a State who does "nothing" in response to another State's claim of rights that may challenge or prejudice its own. Interactions between the unilateral actions by two or more States involved in a certain dispute could lead to an escalation of the dispute; sometimes even armed conflict. In other words, unilateral actions are relevant to maintaining rule of law as well as peace and security in the international system. In relation to the management of maritime disputes, the governance of unilateral actions is arguably no less important than peaceful settlement of disputes. In fact, the former could be an indispensable component of the latter.

More recently, maritime disputes in some parts of the world have resurged and escalated, for example, in the South China Sea; in the East China Sea (particularly over the Senkaku/Diaoyu Islands), or between Israel and Lebanon in the East Mediterranean Sea. The range of actions States undertake vis-à-vis their rival claimants have not only proliferated but also diversified. The legality of some of those actions may also be questioned. Nonetheless, the issue concerning how international law and the law of the sea regulate a State's unilateral conducts in maritime dispute seems to have received much less attention in scholarly writings. This article will be a preliminary attempt to fill this gap. Apart from Introduction and Conclusions, the main body of the article will be divided into the following sections. The first section will provide a general categorization of unilateral actions in maritime boundary disputes, and explores their possible conceptual natures under international law. The second and third sections try to identify rules and principles relevant to States' unilateral

(C) ANNE HSIU-AN HSIAO, 2019 | DOI:10.1163/9789004379633_012

This is an open access article distributed under the terms of the prevailing CC-BY-NC License at the time of publication. 
actions under international law and the law of the sea regime, respectively. Although the article does not aim to address the problem of the conduct of States which arises in a maritime area where one party has an undisputed claim - for example, whether or not a coastal State's reaction to another State's certain activities in its undisputed maritime space is legal - the rules and principles discussed herein may be applied to those situations analogously, and vice versa.

\section{Categorization of Unilateral Actions in Maritime Boundary Disputes}

Under the existing international law of the sea, different issues can arise in maritime boundary disputes. Most often the disputes occurring between two or more States with adjacent or opposite coasts involve competing claims of sovereignty or sovereign rights in areas where these States' maritime claims overlap, including contention over jurisdiction and exclusive rights over living resources or non-living resources within an overlapping exclusive economic zone (EEZ) or a continental shelf. Sometimes the disputes may be associated with the problems of sovereignty over some land features in the maritime area in question. Since maritime spaces are projected on the basis of "land dominates the sea", and a land feature that forms an "island" under the 1982 UN Law of the Sea Convention (UNCLOS) may be entitled to have a 200-mile EEZ and continental shelf (Art. 121(2)), the legal status of such land features and implications of their status may pose additional questions in some of the maritime disputes. Here it is not necessary to provide a comprehensive review of all the activities performed by States in the variety of disputes just mentioned. Suffice is to identify the common types of actions that State undertake in order to assure their legal claims and interests, by reference to relevant State practice.

The first relevant set of actions is associated with those acts that are particularly relevant to the test of "effectiveness" in determining a question of title to territory. The International Court of Justice, which has increasingly been called upon to adjudge territorial sovereignty and boundary disputes between States, has helped identify the general types of such actions. As the court stated in the Territorial and Maritime Dispute (Nicaragua v. Columbia) judgment: "[A]cts and activities considered to be performed a titre de souverain are in particular, but not limited to, legislative acts or acts of administrative control, acts relating to the application and enforcement of criminal or civil law, acts regulating 
immigration, acts regulating fishing and other economic activities, naval patrols as well as search and rescue operations".

States may conduct these actions as an exercise of their sovereignty or rights granted under international law. Or, these acts may represent the attempts by one State to establish or consolidate a territorial claim. When a State takes one of the measures in an area also claimed by another State, the measure may also constitute its response to those acts that have been carried out by that State.

The second set of State actions are related to the settlement of dispute. Under international law, a "dispute" is commonly understood as "a disagreement on a point of law or fact, a conflict of legal views or of interests", ${ }^{2}$ and "it must be shown that the claim of one party is positively opposed by the other". ${ }^{3}$ The most common action States take at the start of a dispute is to issue a diplomatic protest. In a situation where one State believes that its legal rights or interests have been violated by another State, the aggrieved State may pursue one of the following avenues to protect its rights or interests from further damage, and to seek remedy from the perceived harm-doing State: first, by initiating the peaceful dispute-settlement mechanisms under customary international law or according to particular treaty regimes that are applicable to both States; secondly, by adopting unilateral measures vis-à-vis the perceived violating State. In State practice, unilateral measures adopted in relation to a perceived unfriendly act, a violation or to a dispute take many forms. In territorial or boundary disputes, such measures range from non-coercive measures to coercive or even forcible measures. Non-coercive actions include: formal protest or condemnation; some legislative or administrative acts not involving forcible enforcement. Coercive and forcible actions include: limited trade or economic embargo; forcible enforcement such as arresting or expelling ships that are considered as conducting illegal activities in an area claimed by the enforcing State; conducting air or sea patrol or surveillance or military exercise in disputed waters; attempts to establish or "regain" control over territory under dispute by force.

The normal justification for the two sets of unilateral actions is associated with concept of "self-help", "self-protection", or "self-preservation". From the international law perspective, the concept of "self-help" has been founded on the assumption of international law being a horizontal legal system that lacks a supreme authority, the centralization of the use of force, and a differentiation

1 Territorial and Maritime Dispute (Nicaragua v. Columbia), ICJ Judgment, 19 November 2012, para. 80.

2 Mavrommatis Palestine Concessions, Judgment No. 2, P.C.I.J, Series A, No. 2, at 11.

3 South West Africa, Preliminary Objections, ICJ Judgment (1962), at 328. 
of the three basic functions of law-making, law determination, and law enforcement typically entrusted to central organs. ${ }^{4}$ Historically, it was common for States to resort to self-help to enforce their rights and protect their interests. Unilateral actions of self-help were intended to compel the targeted State to cease a perceived wrongful act, whether or not in the political, moral or legal sense, and offer reparation. The means of self-help could be any kind of measures, which had been generally divided into two conceptual forms: retorsion and reprisal. Retorsion refers to any lawful acts of retaliation by one State against another State's unfriendly or unlawful acts. Reprisal involves retaliatory acts that would normally be illegal but which may be rendered lawful by a prior illegal act committed by the targeted State. ${ }^{5}$

International law prior to 1945 had imposed very few restrictions on State's acts of self-help, like the experiences of humanity and good faith in the case of reprisal, ${ }^{6}$ and aggressive war may be regarded as the extreme form of selfhelp. Consequently, it was inevitable that means of self-help were prone to abuse by politically, economically or militarily more powerful States in their bilateral relations with the weaker States. Since 1945, more restrictions have been imposed on reprisals, as a result of progressive developments in international law, particularly the limitations on self-defense and the rules concerning countermeasures under the law of State responsibility. Even though international law has remained largely a decentralized legal system, and acts of selfhelp continue to be a reality of life, States no longer enjoy the same degrees of liberty as before in undertaking any forms of self-help. To put it differently, a State cannot use self-help as a pretext for every action it decides to take against another State even though the latter might have committed an internationally wrongful act. Those rules concerning the lawfulness of "self-help" in international law are significant to the governance of State's unilateral actions in international relations including maritime boundary disputes, and they will be discussed in more detail in the next section.

\section{International Law Relating to the Governance of Unilateral Actions}

One of the main roles international law plays is to maintain stability of international relations. Under the UN Charter, several norms have been developed

4 Peter Malanczuk, Akehurst's Modern Introduction to International LaW 3 (2009).

$5 C f$ Malanczuk, ibid., at 4; Thomas Giegerich, Retorsion, in Max Planck Encyclopedia of Public International Law, available at www.mpepil.com.

6 Bin Cheng, General Principles of LaW: As Applied by International Courts and Tribunals, 97 (1953). 
that are fundamental to the governance of unilateral actions by States in their relations with others. The first of such norms is the principle of peaceful settlement of disputes. As Article 2(3) of the UN Charter stipulates: "All Members shall settle their international disputes by peaceful means in such a manner that international peace and security, and justice, are not endangered". Article 33(1) further provides methods for settling a dispute: "The parties to any dispute, the continuation of which is likely to endanger the maintenance of international peace and security, shall, first of all, seek a solution by negotiation, enquiry, mediation, conciliation, arbitration, judicial settlement, resort to regional agencies or arrangements, or other peaceful means of their own choice. Paragraph 2 of the article entrusts the UN Security Council the power to call upon the parties to settle their dispute peacefully whenever necessary.

Corresponding to the obligation for States to settle their disputes by peaceful means is the obligation for one State to refrain from the threat or use of force against another State. This obligation is stated in Article 2(4) of the UN Charter: "All Members shall refrain in their international relations from the threat or use of force against the territorial integrity or political independence of any state, or in any other manner inconsistent with the Purposes of the United Nations". The only exceptions to this rule are either in a situation of self-defense against an "armed attack", as provided in Article $5^{1}$ of the UN Charter; or military enforcement actions authorized under Chapter vil of the UN Charter. The set of rules prohibiting the threat or use of force is generally regarded as reflecting customary international law, ${ }^{7}$ as well as having acquired the status of jus cogens or peremptory norm. ${ }^{8}$

Within the context of general prohibition of threat or use of force, there are certain aspects that are very pertinent to the conduct of State in territorial disputes. First, the rules concerning the prohibition of threat or use of force are applicable to acquisition of territory. In the ICJ Wall advisory opinion of 9 July 2004, the court referred to UN General Assembly Resolution 2625 (XXV) of 1971, entitled Declaration on Principles of International Law concerning Friendly Relations and Co-operation among States, which states that "No territorial acquisition resulting from the threat or use of force shall be recognized as legal". According to the court, as it had stated in the Nicaragua v. U.s. judgment of 1986, "the principles as to the use of force incorporated in the Charter reflect customary international law ... the same is true of its corollary entailing

7 Case Concerning Military and Paramilitary Activities in and against Nicaragua (Nicaragua v. U.S.), Judgment (1986), paras. 187-190.

8 Christine Gray, International LaW and the Use of Force 29 (2004). 
the illegality of territorial acquisition resulting from the threat or use of force." ${ }^{\prime}$ In addition, force can not be used to settle territorial dispute. In particular, self-defense cannot be invoked as a means to "regain" control of a piece of territory which the initiating State believes that it has a valid claim. Thus, in the Jus Ad Bellum partial award of 19 December 2005, the Eritrea/Ethiopia Claims Commission, in rejecting such an argument forwarded by Eritrea in justifying its taking of the Badme town that was administered by Ethiopia on 12 May 1998, held the view that even though the parties were in dispute concerning the boundary in the Badme area,

However, the practice of States and the writings of eminent publicists show that self-defense cannot be invoked to settle territorial disputes. In that connection, the Commission notes that border disputes between States are so frequent that an exception to the prohibition of the threat or use of force for territory that is allegedly occupied unlawfully would create a large and dangerous hole in a fundamental rule of international law. ${ }^{10}$

Secondly, in the ICJ's dictum in Nicaragua v. U.S. case, it considered the relevant conditions that render a lawful self-defense. One is the existence of an "armed attack". The court took the view that an "armed attack" is to be understood as meaning not merely action by regular armed forces across an international border, but also the sending by a State of armed bands on to the territory of another State, if such an operation, because of its scale and effects, would have been classified as an armed attack had it been carried out by regular armed forces. ${ }^{11}$ The other is that a response in self-defense must meet the criteria of necessity and proportionality. ${ }^{12}$ Since an "armed attack" refers to use of force of more grave scale and effects, the question may arise as to whether or not a State can justify the initiation of a threat or use of force in response to another State's prior forcible actions which do not amount to "armed attacks". With a strict reading of the UN charter or ICJ's dicta, no actual use of force may be justified except for self-defense against an "armed attack". This has been reflected in other legal regimes such as international law concerning State responsibility in relation to the use of countermeasures. ${ }^{13}$ However, in some extreme situations, "threat" of force by a State as a response to limited use of

9 Legal Consequences of the Construction of a Wall in the Occupied Palestinian Territory, 9 July 2004, para. 87 .

10 Jus Ad Bellum partial award, para. 10.

11 Nicaragua v. U.S., paras. 187-190.

12 Ibid., Legality of the Threat or Use of Nuclear Weapons, advisory opinion of 8 July 1996, paras. 41-42.

13 More discussions below. 
force by another State might not be entirely ruled out. A case in point may be the British responses to the firings of Albania at two of its warships in the Corfu Channel case. In response to the firings on 15 May 1946, the United Kingdom sent warships through the North Corfu Strait on 22 October 1946. Albania contended, among others, that the passage of the British warships "was not an ordinary passage, but a political mission", because of reasons including: the ships were maneuvering and sailing in a combat formation with soldiers on board; the numbers of the ships and their armaments surpassed what was necessary in order to attain their object and showed an intention to intimidate and not merely to pass, etc. ${ }^{14}$ The court observed that the UK had admitted that the object of sending the warships through the channel was not only to carry out a passage for purposes of navigation, but also to test Albania's attitude and assert its right of innocent passage. Also, the ships were at action stations so that they might retaliate quickly if fired upon again by Albania again, and they passed through the narrow channel close to the Albanian coast. The court held that the intention of the UK "must have been, not only to test Albania's attitude, but at the same time to demonstrate such force that she would abstain from firing again on passing ships", and concluded that the measures taken by UK did not violate Albanian sovereignty. ${ }^{15}$ It appears that threat of force might be justified if a State which has been a victim of limited force by another State resorts to this means to deter the latter State from committing another act of force. That said, it should be stressed that even if an aggrieved State might be justified in resorting to "threat" in response to another State's use of force during peace time, such an option must be taken with extreme caution, and the established criteria for lawful self-defense should also apply.

The development of jus ad bellum has brought about serious limitations on State's use of force as a means of self-help. In addition, the issues concerning certain forms of self-help, namely "countermeasures", have attracted considerable attention in relation to the development of the law of State responsibility. During the long-running work of the International Law Commission on State responsibility, one of its most important tasks has been to establish a satisfactory regime for the settlement of dispute. Within the context of dispute settlement, the issue of disputes over countermeasures was regarded as of particular significance. ${ }^{16}$ The Draft Articles Responsibility of States for Internationally Wrongful Acts adopted by the International Law Commission

\footnotetext{
14 The Corfu Channel Case (Merits), Judgment of 9 April 1949, at 30.

15 Ibid., at 31 .

16 James Crawford, Counter-measures as Interim Measures, 5 EURopeAn Journal of INTERNATIONAL LAW 65 (1994).
} 
in 2001 contains a provision (Article 22$)^{17}$ that permits a State to take nonforcible means of reprisal, i.e., countermeasures, towards another State which has first committed a wrongful act under international law against itself, provided such measures meet certain condition. The first condition is that such measures are confined to non-forcible means of reprisal. The ILC has excluded belligerent reprisals from the scope of countermeasures under the Draft Articles on State Responsibility. It also distinguishes countermeasures with retorsion, namely unfriendly conduct which is not inconsistent with any international obligation of the State engaging in it, such as the prohibition of or limitation upon normal diplomatic relations or other contacts; embargos of various kinds or withdrawal of voluntary aid programs. ${ }^{18}$ Permissible countermeasures are subjected to a number of requirements and limitations: First, the nature of the acts concerned must be non-forcible. They preclude the threat or use of force. (Draft Article 5o(1)(a); Secondly, countermeasures should be directed at the responsible State and not at third parties. (Draft Article 49 (1) \& (2)). Thirdly, countermeasures are instruments used to bring about cessation of and reparation for the internationally wrongful act and not a means of punishment. Therefore, they are temporary in nature and must be as far as possible reversible in their effects in terms of future legal relations between the two States concerned. (Draft Articles 49 (2), (3) and 53). Fourthly, countermeasures must be proportionate. (Draft Article 51). Fifth, countermeasures should not involve any breach of fundamental obligations under international law, particularly refraining from the threat or use of force; protection of fundamental human rights; refraining from reprisals based on humanitarian considerations; other peremptory norms of general international law. (Draft Article 50 (1). ${ }^{19}$ Sixthly, countermeasures should meet the requirement of necessity. (Draft Article 25) The state of necessity arises under exceptional circumstances where the only way a State can protect an essential interest threatened by a "grave and imminent peril" is to take an action that is in breach of one of its international obligations. In ICJ's decision on

17 Article 22 reads as follows:

"Countermeasures in respect of an internationally wrongful act. The wrongfulness of an act of a state not in conformity with an international obligation towards another state is precluded if and to the extent that the act constitutes a countermeasure takes against the latter state in accordance with Chapter II of Part Three".

18 James Crawford, The International Law Commission's Articles on State Responsibility: Introduction, TeXt And Commentaries 281 (2002).

Cf. CRAWFORD, supra note 18 , at 283 . 
Gabcikovo - Nagymaros Project case of $1997,{ }^{20}$ the court considers that the state of necessity is a ground recognised by customary international law for precluding the wrongfulness of an act not in conformity with an international obligation. Such ground for preclusion can only be accepted on an exceptional basis. The conditions for establishing such an exception need be strictly defined, which must be "cumulatively satisfied", and the State concerned would not be the sole judge of whether those conditions have been met. ${ }^{21}$ The court drew from earlier ILC drafts the following conditions which reflect customary international law and were relevant to the identification of the existence of an "exceptional case": First, the State authoring the response otherwise in breach of one of its international obligations must have been occasioned by one of its "essential interests" being threatened by a "grave and imminent peril". Secondly, the act being challenged must have been the "only means" of safeguarding that interest. Thirdly, that act must not have "seriously impair[ed] an essential interest" of the State towards which the obligation existed; and finally, the State which is the author of the countermeasure must not have "contributed to the occurrence of the state of necessity. ${ }^{22}$ These conditions have been consistently reflected in Draft Article 25 adopted by ILC in 2002. ${ }^{23}$ All of the six requirements have been drawn from relevant State practice and are supported by the jurisprudence of major international cases. ${ }^{24}$ Hence, they may be regarded as general principles of international law.

Finally, certain rules concerning the acquisition of territory may also play a role in determining the legal effect of unilateral actions of States in territorial disputes. One example may be the test of "critical date". The ICJ has consistently held that "it cannot take into consideration acts having taken place after the date on which the dispute between the parties crystallized unless such acts are a normal continuation of prior acts and are not undertaken for the purpose of improving the legal position of the Party which relies on them". ${ }^{25}$

20 Gabcikovo - Nagymaros Project (Hungary v. Slovakia), I.C.J. Judgment of 25 September 1997.

$21 \quad$ Ibid., para. 51.

22 Ibid., para. 52.

23 Crawford, supra note 18 , at 183.

24 More recently in the Legal Consequences of the Construction of a Wall in the Occupied Palestinian Territory, Advisory Opinion, ICJ Rep 136, (2004) 43 ILM 1009, 9th July 2004, International Court of Justice, at para. 140.

25 Columbia v. Nicaragua, judgement, para. 68; Sovereignty over Pulau Ligitan and Pulau Sipadan (Indonesia/Malaysia), Judgment, para. 135. 


\section{Relevant Rules under International Law of the Sea Regime}

UNCLOS has incorporated the main basic rules and principles of international law. The general principles of good faith and abuse of rights are stipulated in Article 300 of the convention. State parties are bound to fulfill their obligations under UNCLOS in good faith, and shall exercise their rights, jurisdiction and freedom recognized under the convention in a manner without unnecessarily or arbitrarily harming the rights of other States or the interests of the international community as a whole, or amounting to the misuse of power. ${ }^{26}$ The language of Article 300 shows the inter-linkage between the two principles. The principle prohibiting the threat or use of force is embodied in Article 301 of the convention. The principle of peaceful settlement of dispute has been given significant weight in the UNCLOS. In particular, Part XV (Articles 279 - 299) of the convention is entirely devoted to the principles and mechanisms concerning the settlement of disputes. Article 279 provides that "State parties shall settle any dispute between them concerning the interpretation or application of this Convention by peaceful means in accordance with Article 2, paragraph 3, of the Charter of the United Nations, and to this end, shall seek a solution by means indicated in Article 33, paragraph 1, of the Charter".

In addition to those provisions that reflect existing rules of international law, special rules have also been developed under UNCLOs to deal with the relationship between and the unilateral conduct of State parties in maritime boundary disputes. For example, Article 123 requires States bordering an enclosed or a semi-enclosed sea to cooperate with each other. The most relevant provisions may be found in Articles 74 and 83 of the Convention. The two articles contain identical terms that deal respectively with the delimitation of EEZ and continental shelf between States with opposite or adjacent coasts. According to these articles, States concerned shall resolve the problem of delimitation by agreement in accordance with international law. (Paragraph 1) In the case that no agreement can be reached with a reasonable period of time, the States concerned shall resort to the dispute settlement procedures under Part XV of the UNCLOS. (Paragraph 2) Pending agreement on delimitation, "[T]he States concerned, in a spirit of understanding and co-operation, shall make every effort to enter into provisional arrangements of a practical nature and, during this transitional period, not to jeopardize or hamper the reaching of the final agreement. Such arrangements shall be without prejudice to the final delimitation". (Paragraph 3)

26 Cf. Nordquist, et al (Eds.), Commentary of the United Nations Law of the Sea Convention, Volume v 150-152 (1989). 
Finally, where there is an agreement in force between the States concerned, questions relating to the delimitation of EEz/continental shelf shall be determined in accordance with the provisions of that agreement. (Paragraph 4)

Controversies over the legality of unilateral actions or countermeasures of two or more States with opposite or adjacent coasts can easily arise in the areas of overlapping EEZ or continental shelf claims. Until the maritime boundary is finally delimited, whether by agreement between the States concerned, or through third-party decisions, in theory the claimant States concerned are entitled to claim equal rights and jurisdiction within the overlapping areas. ${ }^{27}$ As a result, whenever a State, in accordance with UNCLOS, exercises its rights or competence in relation to the overlapping EEZ or continental shelf, such as enforcing jurisdiction or exercising exclusive rights over living or non-living natural resources, those acts will have an impact on the rights and interests of other States that also make claims to the same area. Accordingly, Articles 74 and 83 of the UNCLOS lay down basic principles and procedures for States facing overlapping EEz or continental shelf claims to conduct themselves and manage their disputes in accordance with the convention. However, Articles 74 and 83 have some notable limitations. First, while paragraph 2 imposes State parties the duty to resort to the dispute settlement mechanism in Part XV, if no agreement on delimitation can be reached within a reasonable period of time, the provision does not define what "reasonable" means. Also, Part XV concerns mainly the settlement of disputes regarding the interpretation or application of UNCLOS. (Article 279); and the means of settling a dispute primarily still depend on the agreed choices between the State parties concerned. The compulsory procedures entailing binding decision provided under Section 2, Part $\mathrm{XV}$ are subjected to limitations in Section 3, under which disputes relating to maritime boundary delimitations (Articles 15, 74, 83) can be excluded from the binding compulsory procedures by a declaration of the States concerned. The issues of territorial sovereignty are also excluded. Consequently, it is possible that negotiations on boundary delimitations can go on for a long time without any prospect for solution, particularly if States concerned are not willing to submit their dispute to a third-party decision.

Secondly, while paragraph 3 of Articles 74 and 83 has offered a progressive approach ${ }^{28}$ for States to manage their legal relations before the issue of

27 David M. Ong, Joint Development of Common Offshore Oil and Gas Deposits: Mere Sate Practice or Customary International Law?, 93 AMERICAN JOURNAL OF INTERNATIONAL LAW 771-804, 773. (1999).

28 According to Rainer Lagoni, the drafting history of paragraph 3 of Articles 74 and 83 confirms that "it is in no way a codification of customary international law but represents an example of its progressive development", Rainer Lagoni, Interim Measures Pending 
delimitation is resolved, the terms of the paragraph seem so vague that difficulties can arise in regard to its interpretation. Paragraph 3 of Article 74 and 83 imposes dual obligations on States involved in either an EEZ or a continental shelf boundary delimitation dispute pending an agreed settlement. On the one hand, States concerned have a positive duty to make every effort to enter into provisional arrangements of a practical nature. On the other hand, during the transitional period, States concerned have a negative (or restrictive) duty not to jeopardize or hamper the reaching of the final agreement. However, the article provides no direct guidance for assessing issues such as when a State can be said to have fulfilled its obligation of "making every effort"; or whether or not a certain measure or situation amounts to "jeopardizing or hampering" the reaching of a final agreement, which can result in more disputes.

The drafting history of Articles 74 and 83, as well as a few international judicial cases has helped providing some clarifications to paragraph 3. To begin with, the draft history reveals that the article was not intended to impose a general moratorium on all activities in the overlapping EEZ or continental shelf. Rather, paragraph 3 was a negotiated compromise that allows continued utilization of the area to be delimited by the States concerned without jeopardizing or hampering the reaching of the final delimitation agreement and without prejudice to the existing claims or positions of the parties concerned. It is suggested that the provision reflects the general principle of "good faith". In regard to the positive duty, it has been widely supported that the basic duty of States concerned is to enter into negotiation in good faith. This applies to both delimitation in paragraph 1 and "provisional arrangements" in paragraph 3. In the North Sea Continental Shelf cases, the ICJ described the obligation to negotiation in good faith as "a principle which underlines all international relations", and stressed that such an obligation must be "meaningful". According to the court: "the parties are under an obligation to enter into negotiations with a view to arriving at an agreement, and not merely to go through a formal process of negotiation as a sort of prior condition for the automatic application of a certain method of delimitation in the absence of agreement; they are under an obligation so to conduct themselves that the negotiations are meaningful, which will not be the case when either of them insists upon its own position without contemplating any modification of it". ${ }^{29}$

Maritime Delimitation Agreements, 78 American Journal of International LaW 345-368, 354 (1984).

29 North Sea Continental Shelf Cases (Germany v. Demark/Germany v. the Netherlands), Judgment of 20 February 1969, para. 85(a). 
With regard to the negative duty, namely the obligation not to jeopardize or hamper the reaching of the final agreement during the transitional period, the drafting history shows that the proposals to prohibit a State concerned from unilaterally undertaking all economic activities in a disputed maritime area, particularly exploration or exploitation of natural resources, were not adopted. Instead, this part of the article has created a duty to exercise mutual restraint for States involved in a boundary delimitation challenge. Such restraint is necessary since the unilateral use of the overlapping area by one State concerned will inevitably affect the rights and position of other States which also claim the area. According to a more pragmatic interpretation, States concerned should be free to exercise their rights and jurisdiction in an area of overlapping claims so long as they pay due regard to the rights of the other coastal States. ${ }^{30}$ The crucial consideration for prohibiting certain unilateral actions will be whether or not those actions threaten to cause "irreparable prejudice" to the rights of the parties concerned or to the reaching of a final agreement. Thus, unilateral exploitation of oil or gas resources on a disputed continental shelf is generally regarded to be prohibited, while unilateral exploratory activities may raise some uncertainties.

The exact issue has come before the ICJ in 1976 in the disputes over Aegean Sea Continental Shelf between Greece and Turkey. Among others, Greece requested the court to indicate interim measures of protection under Article 41 of the ICJ Statute, ${ }^{31}$ with regard to Turkey's alleged violations to its exclusive sovereign rights in the continental shelf which it claimed. Greece claimed that Turkey had violated its exclusive sovereign rights over its continental shelf in the Aegean Sea and caused irreparable prejudice to its exclusive rights to acquire information concerning the availability, extend and location of natural resources of the areas by granting permits in 1973 to Turkish State petroleum company for oil exploration and conduct seismic research during 1976, in an area over the continental shelf claimed by Greece based on certain Greek islands in the Aegean Sea. It also claimed that the activities complained would, if continued, aggravate or extend the dispute. Greece asked the court to direct both governments to (1) unless by mutual consent and pending the final judgment of the court in this case, refrain from all exploration activity or any scientific research in certain designated areas of the continental shelf; and (2) to

$30 \quad$ Lagoni, supra note 28 , at 365 .

31 In particularly, Article 41, paragraph 1 of the Statute provides: "The Court shall have the power to indicate, if it considers that circumstances so require, any provisional measures which ought to be taken to preserve the respective rights of either party". 
refrain from taking further military measures or actions which may endanger their peaceful relations. ${ }^{32}$

The court considered that its power to indicate interim measures ought to be exercised when the rights of the parties concerned "might not be restored in full measures in the event of a judgment if that judgment is anticipated" 33 In the court's view, the Turkish activities complained by Greece had taken place in "an area in dispute", with respect to which Turkey also claims sovereign rights of exploration and exploitation. ${ }^{34}$ The court stressed that "neither concessions unilaterally granted nor exploration activities unilaterally undertaken by either of the interested States concerned with respect to the disputed areas can be creative of new rights or deprive the other States of any rights to which in law it may be entitled". 35 The court also carefully examined the seismic operation conducted by Turkey. It found that the type of method used in the research had not been alleged to involve "any risk of physical damage to the seabed or subsoil or to their natural resources". The Turkish activities were all of the "transitory character", and "do not involve the establishment of installations on or above the seabed of the continental shelf". Neither had Turkey conducted any operations involving the actual appropriation or other use of natural resources of the areas of the continental shelf under dispute. ${ }^{36}$ Based on these findings, the court did not think that there existed a risk of an "irreparable prejudice" to the rights at issue to justify recourse to its power to indicate interim measures of protection under Article $41 .{ }^{37}$ The ICJ also rejected the request by Greece to order both States to refrain from military measures, by the reason that the request did not fall within the scope of Article 41. However, it did emphasize that the mutual obligations of Greece and Turkey under Article 2 (4) and Article 33 "are clearly imperative in their mutual relations, and in particular in regard to their present dispute concerning the continental shelf in the Aegean". 38

The ICJ's deliberations of the "irreparable prejudice" of rights of parties concerned, and particularly the test of "any risk of physical damage to seabed or subsoil or their natural resources" for determining prohibitive actions in overlapping continental shelf are instructive. They are supported and supplemented by the UNCLOS and judicial decisions under the aegis of the treaty.

\footnotetext{
32 Aegean Sea Continental Shelf Case (Greece v. Turkey), Order of 11 September 1976, para. 2.

33 Ibid., para. 27.

34 Ibid., para. 28.

$35 \quad$ Ibid., para. 29.

$36 \quad$ Ibid., para. 30.

37 Ibid., paras. $3^{2-33}$.

$38 \quad$ Ibid., para. 35 .
} 
Article 290 of UNCLOS endows a court or tribunal with prima facie jurisdiction over a dispute submitted to it under Part XV or Part XI, section 5, with the competence to prescribe any provisional measures which it considers appropriate under the circumstances to preserve the respective rights of the parties to the dispute or to prevent serious harm to the marine environment, pending final decision. It appears that the test of "irreparable damage" may analogously apply to a dispute arising in an overlapping territorial sea area, as suggested in the Land Reclamation case of 2003 between Malaysia and Singapore. ${ }^{39}$

More significantly, the Guyana/Suriname arbitral award of $2007^{40}$ is the first case where an international tribunal provides a detailed and authoritative interpretation and analysis of paragraph 3 of Articles 74 and 83 of the UNCLOS, taking account of both general international law and the relevant rules under the law of the sea. The case involves, inter alia, disputes between Guyana and Suriname, with regard to the lawfulness of certain unilateral actions and countermeasures conducted by each State over an area where the two States' claims of EEZ and continental shelves overlapped, in relation to an incident taking place on 3 June 2000. In the award, the arbitral tribunal established under Article 287 and Annex VII of the UNCLOS, made several points that are directly relevant to the present discussion:

First, the general principle prohibiting the threat or use of force under international law is applicable in a maritime delimitation dispute. Whether or not a particular situation constitutes the illegal threat or use of force depends on the merits of each case. In the Guyana v. Suriname case, the tribunal considered that the issuance of warning by the Suriname naval patrol boats to Guyana licensed foreign ships operating exploratory activities in the disputed area "to leave or face consequences" on 3 June 2000 amounted to unlawful threat of force. (para. 439) As a result, the court rejected Suriname's argument that the actions were lawful exercise of "law enforcement", even though it did recognize that under international law, force may be used in law enforcement activities, provided that such force is unavoidable, reasonable and necessary. (para. 445)

39 Case concerning Land Reclamation by Singapore in and around the Straits of Johor, (Malaysia v. Singapore), Order of 8 October 2003, paras. 23, 72. The International Law of the Sea Tribunal did not find that there was a situation of urgency or that there is a risk that the rights claimed by Malaysia with respect to an area of territorial sea would suffer "irreversible damage" pending consideration of the merits of the case by an arbitral tribunal established under Annex VII of the UNCLOS to render the court's prescription of provisional measures appropriate, para. 73 .

40 Guyana and Suriname, Award of the Arbitral Tribunal Constituted pursuant to Article 287 and in accordance with Annex VII of the United Nations Convention on the Law of the Sea, 17 September 2007. 
It also rejected its argument that those measures were lawful countermeasures in response to Guyana's internationally wrongful act in order to achieve cessation of that act. The tribunal held that peaceful means of addressing Guyana's alleged breach of international law were available to Suriname under UNCLOS (Part XV, Section 2 or recourse to provisional measures under Article 290). However, instead Suriname quickly resorted to measures involving threat of force, which could not have been lawful. (para. 446.)

Secondly, with regard to the positive duty contained in paragraph 3 of Articles 74 and 83 , the arbitral tribunal opined that this obligation implicitly acknowledges the importance of avoiding the suspension of economic development in a disputed maritime area, as long as such activities do not affect the reaching of a final agreement. (para. 46o) In addition, the language of the obligation imposes upon the parties a duty to negotiate in good faith, in the pursuit of a provisional arrangement. (para. 461) In this case, the tribunal found that Suriname did not fulfill its obligation to make every effort to enter into provisional arrangement with Guyana before or after the relevant disputes arose. In particular, after Suriname became aware of Guyana's concession holder's planned exploratory drilling in disputed waters, it decided to resort to self-help by issuing threat, instead of actively trying to engage Guyana in negotiation, or at least could have accepted Guyana's last minute invitation and negotiated in good faith and insisted during negotiation on the immediate cessation of the drilling plan as a condition to participation in further talks. (para. 476) Conversely, the tribunal also ruled that Guyana violated its positive duty by its conduct leading up to the incident on 3 June 2000. In the tribunal's opinion, Guyana should have been preparing exploratory drilling for some time before the incident. It should have informed Suriname directly of its plans instead of merely a press notification from the license holder and only tried to discuss about the modalities of it's the activities in the last minute. In short, Guyana should have tried to engage Suriname at a much earlier stage. Steps that it could have taken in accordance with the positive duty include (1) give Suriname official and detailed notice of its planned activities; (2) seeking cooperation of Suriname in undertaking the activities; (3) offering to share the results of the exploration and giving Suriname an opportunity to observe the activities, and (4) offering to share all the financial benefits received from the exploratory activities. (para. 477)

Thirdly, with regard to the negative duty contained in paragraph 3 - the duty not to hamper or jeopardize the reaching of a final agreement - the tribunal followed a similar line of reasoning as the ICJ did in its 1976 order in regard to the Aegean Sea. It made a legal distinction between two types of exploratory activities - seismic testing and exploratory drilling, and considered that only 
those unilateral exploratory activities that "might cause permanent damage to the marine environment" in the area in dispute will lead to a violation of this duty, like exploratory drilling. Such activities should be "frozen in absence of a provisional arrangement" entered into by the parties concerned. By contrast, seismic activity ${ }^{41}$ should be permissible in a disputed area. (para. 481) In case of an alleged violation to the negative obligation, and if bilateral negotiations failed to resolve the issue, a remedy is set out in the options for peaceful settlement under Part XV and Annex VII of UNCLOS, and States parties concerned should make use of such mechanism. (para. 482)

\section{Conclusions}

In the light of the above investigation, it is clear that international law and the law of the sea regime do not prohibit all unilateral actions in maritime boundary disputes. However, unilateral actions do not exist in a "lawless" domain, either. Even though States may be the "masters of their own affairs", their power of discretion and resultant actions are expected to be guided and sanctioned by the existing principles and rules of international law, such as good faith, prohibition of threat or use or force, and peaceful settlement of disputes. This applies equally to States' unilateral actions in relation to territorial or boundary disputes, either land or maritime. Therefore, threat or actual use of force cannot be used except in the strictly defined contexts of self-defense or selfhelp. It cannot be initiated by States to regain territory or resolve territorial or boundary disputes. Under the UNCLOS regime, special rules have also been formulated that require States involved in EEZ or continental shelf delimitation disputes to actively cooperate with each other and to pay due regard to each other's rights and interests. The relevant obligations of States concerned include: to engage with one another in "meaningful negotiation" with regard to delimitation and related disputes, or concerning provisional arrangements to utilize resources in the overlapping areas, such as joint development or information - or profit - sharing; to conduct themselves in a manner consistent with relevant rules of international law, and without causing "irreparable damage" to the legal rights and interests of other State concerned or to the marine environment. Excessive enforcement actions and arbitrary or unreasonable

$41 \quad$ Seismic exploration is carried out by vessel traversing the surface of the high sea and causing small explosions to occur at intervals under water. These explosions will send sound waves through the seabed so as to provide information regarding the geophysical structure of the earth beneath it, Aegean Sea, ICJ Order of 1976, para. 30. 
unilateral measures in overlapping maritime areas may constitute violations of good faith or abuse of rights, and could incur international responsibility. On the other hand, there also seems to be a trend towards gauging the legitimacy of countermeasures by taking into account whether the aggrieved State has first resorted to options of dispute settlement of disputes available to it to address the other State's perceived violation or protect its rights or interests before adopting those measures. With consistent interpretation by international courts and tribunals, those rules may be gaining importance. Consequently, while unilateral actions will continue to be an indispensable instrument for States demonstrate effectiveness or to address legal violation or non-compliance by other States in the foreseeable future, including acts of retorsion and legitimate countermeasures, international law and the law of the sea regime have provided some useful guidance that could help States avoiding the risk of aggravating disputes and law-breaking as a result of their arbitrary and excessive actions, and increasing the possibility of mutual confidence and cooperation. 